\title{
Constituents of the Pollen of Crocus sativus L. and Their Tyrosinase Inhibitory Activity
}

\author{
Chia-Ying LI and Tian-Shung $\mathrm{Wu}^{*}$ \\ Department of Chemistry, National Cheng Kung University; Tainan 701, Taiwan. \\ Received March 15, 2002; accepted June 3, 2002
}

\begin{abstract}
Five new naturally occurring monoterpenoids, crocusatins-A (1), -B (2a), -C (3), -D (4a) -E (5), a new lactate, sodium ( $2 S)$-( $O$-hydroxyphenyl)lactate (6), and eighteen known compounds were isolated and characterized from the pollen of Crocus sativus $\mathrm{L}$. The tyrosinase inhibitory activities of these compounds were also discussed.
\end{abstract}

Key words Crocus sativus L.; saffron; Iridaceae; pollen; monoterpenoid; tyrosinase inhibition

Crocus sativus L., commonly known as saffron, is a stemless perennial herb of the Iridaceae. It is distributed in South Europe, Middle Iran and South Asia, and has been cultivated in mainland China. This plant is highly economical because it can be used as a dye for coloring and as a spice for food preparations. The stigma of this plant is a well-known traditional Chinese medicine and is used similarly to safflower (Carthamus tinctorius L.), with stronger action to stimulate blood flow and relieve pain by removing stagnated blood; it is used in the treatment of amenorrhea, menostasis, melancholia, chest and abdominal pain, painful swellings due to bloodstasis, hepatomegaly, splenomegaly, convulsion, pain of traumatic wounds, and as a sedative. ${ }^{1)}$ Earlier investigations have reported the isolation of carotenoids, monoterpenoids, flavonoids, anthocyanins from the stigma, leaves, petals and pollen of this plant, ${ }^{2-13}$ as well as the use of saffron as an important phytotherapeutic agent. $^{9-11)}$ In our search for novel biologically active compounds from natural sources, we were interested in the constituents of the pollen of $C$. sativus due to its significant antityrosinase activity. Bioassaydirected fractionation of the methanolic extract led to the isolation and characterization of five new naturally occurring monoterpenoids, crocusatins-A (1), -B (2a), -C (3), -D (4a), and -E (5), and a new lactate, sodium $(2 S)$ - $(O$-hydroxyphenyl)lactate (6), along with eighteen known compounds (7-24). Among them, isorhamnetin-3,4'-diglucoside (20) has been characterized as a strong tyrosinase inhibitor.

Crocusatin-A (1) was isolated as an optically active colorless oil. Its molecular formula was determined to be $\mathrm{C}_{9} \mathrm{H}_{14} \mathrm{O}_{2}$ by high-resolution mass spectrometry (HR-MS). The IR absorption bands at 3500 and $1672 \mathrm{~cm}^{-1}$ and UV absorption at $232 \mathrm{~nm}$ indicated the presence of a hydroxyl group and a conjugated carbonyl group in the molecule. The ${ }^{1} \mathrm{H}-\mathrm{NMR}$ of 1 showed the presence of a gem-dimethyl group at $\delta 1.15$ and 1.11 , a vinyl methyl group at $\delta 1.79$, an ABX system at $\delta$ $4.58(1 \mathrm{H}, \mathrm{ddd}, J=5.2,2.4,1.6 \mathrm{~Hz}), 2.15(1 \mathrm{H}, \mathrm{dd}, J=12.8$, $5.2 \mathrm{~Hz})$ and $1.83(1 \mathrm{H}, \mathrm{dd}, J=12.8,2.4 \mathrm{~Hz})$, and a vinyl proton at $\delta 6.60(1 \mathrm{H}, \mathrm{d}, J=1.6 \mathrm{~Hz})$. The signal at $\delta 4.58$ was assigned to an oxygenated methine proton. To establish the planar structure of $\mathbf{1}$, a heteronuclear multiple-bond correlation (HMBC) experiment (Fig. 1) was conducted. The gem-dimethyl ( $\delta 1.11$ and 1.15$)$, vinyl methyl $(\delta 1.79)$, methylene $(\delta 2.15,1.85)$ and vinyl $(\delta 6.60)$ protons showed ${ }^{3} J$ correlation to the carbonyl carbon $(\delta$ 203.6). Therefore, the carbonyl group must be located at $\mathrm{C}-1$. The relative stereochemistry of a chiral center of the ring was deduced from the cou- pling constant of H-4 and from a nuclear Overhauser enhancement spectroscopy (NOESY) experiment (Fig. 2). The results showed that $\mathrm{H}-4(\delta$ 4.58) was within NOE distance from methylene protons $(\delta 2.15,1.83)$ and vinyl proton $(\delta$ $6.60)$. The coupling constant of $\mathrm{H}-4(J=5.2,2.4,1.6 \mathrm{~Hz})$, coupled with the NOE experiment, suggested that the H-4 was located at the equatorial. The absolute configuration at C-4 was determined to be $S$. because Widmer et al. had synthesized (4S)-4-hydroxy-2,6,6-trimethyl-cyclohex-2-en-one and shown a negative optical rotation. ${ }^{14)}$ Crocusatin-A also displayed the same optical rotation. Based on the evidence, structure 1 was assigned to crocusatin-A. This is the first report of 1 from the natural source.

Crocusatin-B (2a) was isolated as an optically active colorless powder. The molecular formula was established as $\mathrm{C}_{10} \mathrm{H}_{16} \mathrm{O}_{3}$ by HR-MS. The presence of an $\alpha, \beta$-unsaturated carboxylic acid was indicated by IR and UV absorption bands at $1651 \mathrm{~cm}^{-1}$ and at $221 \mathrm{~nm}$, respectively, together with ${ }^{13} \mathrm{C}-\mathrm{NMR}$ signals at $\delta 181.6$ (s), 142.0 (s), 124.1 (s). Compound 2 a contained 10 distinct carbon signals attributable to three methyls (one vinylic and two geminal on a quaternary carbon), two methylenes, one methine bearing oxygen, and four quaternary carbons (two olefinic, one carbonyl) from the heteronuclear multiple quantum coherence (HMQC) experiment spectrum. The ${ }^{1} \mathrm{H}-\mathrm{NMR}$ spectrum of $\mathbf{2 a}$ showed signals for the gem-dimethyl group $(\delta 1.12,1.22)$, and a vinyl methyl group ( $\delta$ 1.68). A multiplet signal at $\delta$ $3.93(1 \mathrm{H}$, dddd, $J=9.6,8.0,6.0,3.6 \mathrm{~Hz})$ was interpreted as a methine proton which was germinated to a secondary alcohol and coupled with two sets of methylene protons at $\delta 2.23$ $(1 \mathrm{H}, \mathrm{dd}, J=16.4,6.0 \mathrm{~Hz}), 1.88(1 \mathrm{H}, \mathrm{dd}, J=16.4,9.6 \mathrm{~Hz})$, $1.67(1 \mathrm{H}, \mathrm{dd}, J=8.0,3.6 \mathrm{~Hz})$ and $1.38(1 \mathrm{H}, \mathrm{t}, J=8.0 \mathrm{~Hz})$. The
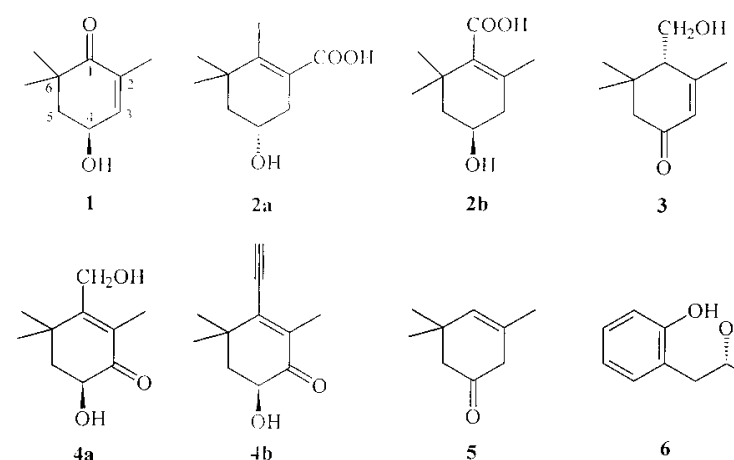

2:1

$2 \mathbf{b}$

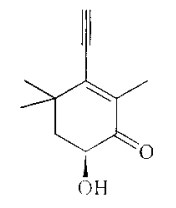

tb
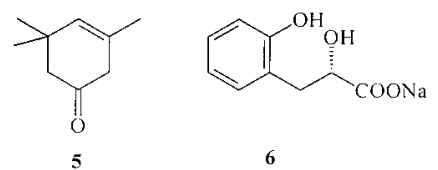

Chart 1 

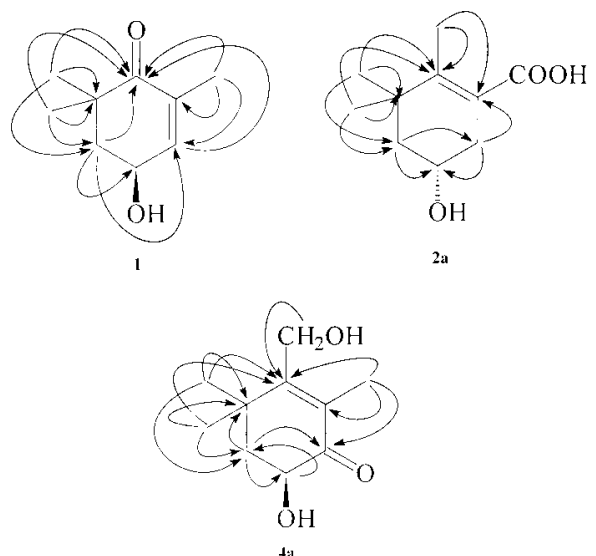

Fig. 1. The HBMC Correlations of 1, 2a, and 4a

${ }^{1} \mathrm{H}-{ }^{1} \mathrm{H}$ shift correlation spectroscopy (COSY) and HMQC and HMBC (Fig. 1) experiments established the connectivities and planar structure of the molecule. The relative stereochemistry of 2a at C-4 was determined by the coupling constant of H-4 and by a NOESY experiment (Fig. 2). The NOEs were observed between $\mathrm{H}-4$ and Me- 8 ( $\delta 1.22), \mathrm{H}-5_{\text {eq }}$ $(\delta 1.67)$ and $\mathrm{H}-3_{\mathrm{eq}}(\delta 2.23)$, respectively. Thus, the hydroxyl group at $\mathrm{C}-4$ must be located at an equatorial orientation. Takeda et al. obtained (4S)-4-hydroxy-2,6,6-trimethylcyclohex-1-ene carboxylic acid (2b) as an aglycone of natural glucoside, and it showed a negative optical rotation. ${ }^{15)}$ However, crocusatin-B displayed a positive optical rotation. Therefore, the absolute configuration of $\mathbf{2 a}$ at $\mathrm{C}-4$ was proposed to be $R$, and the structure of crocusatin-B was assigned as $\mathbf{2 a}$.

Crocusatin-C (3) was obtained as a colorless oil, and its molecular formula, $\mathrm{C}_{10} \mathrm{H}_{16} \mathrm{O}_{2}\left(\mathrm{M}^{+}\right.$at $m / z$ 168.1156), indicated three degrees of unsaturation. The following spectroscopic evidence revealed that compound $\mathbf{3}$ should be a monocyclic monoterpenoid, with a ketonic group conjugated with a trisubstituted double bond $\left[\lambda_{\max } 239 \mathrm{~nm} ; v_{\max } 1670 \mathrm{~cm}^{-1}\right.$; $\delta_{\mathrm{H}} 5.98(1 \mathrm{H}, \mathrm{s}), 2.03(3 \mathrm{H}, \mathrm{s}) ; \delta_{\mathrm{C}} 199.7(\mathrm{~s}), 127.6(\mathrm{~d}), 160.8$ $(\mathrm{s}), 23.9(\mathrm{q})]$; a gem-dimethyl $\left[\delta_{\mathrm{H}} 1.03,1.15(\right.$ each $3 \mathrm{H}, \mathrm{s}) ; \delta_{\mathrm{C}}$ $35.4(\mathrm{~s}), 29.4(\mathrm{q}), 27.1(\mathrm{q})]$; a methylene $\left[\delta_{\mathrm{H}} 2.05,2.63\right.$ (each $\left.1 \mathrm{H}, \mathrm{d}, J=17.2 \mathrm{~Hz}) ; \delta_{\mathrm{C}} 48.5(\mathrm{t})\right]$. In addition, the ${ }^{1} \mathrm{H}-\mathrm{NMR}$ and $\mathrm{HMQC}$ spectra appeared an $\mathrm{ABX}$ type signals at $\delta 3.95$ $(1 \mathrm{H}, \mathrm{dd}, J=11.6,3.6 \mathrm{~Hz}), 3.88(1 \mathrm{H}, \mathrm{dd}, J=11.6,3.6 \mathrm{~Hz})$ and $1.99(1 \mathrm{H}, \mathrm{t}, J=3.6 \mathrm{~Hz})$, which was attributed to the oxygenated methylene $\left(\delta_{\mathrm{C}} 61.5\right)$ protons, $\mathrm{H}-7 \mathrm{a}, \mathrm{H}-7 \mathrm{~b}$ and $\mathrm{H}-1$, respectively. According to the above data, compound $\mathbf{3}$ has an isophorone skeleton of monoterpene, which possesses a hydroxyl group at $\mathrm{C} 10$. The relative stereochemistry of H-1 was determined to be an equatorial orientation based on the cross-peaks between $\mathrm{H}-1$ and methylene protons $\left(\delta_{\mathrm{H}} 3.95\right.$, 3.88 ), one of the gem-dimethyl and vinylic methyl protons in the NOESY spectrum (Fig. 2). From the above results, structure 3 was assigned for crocusatin-C. Though this compound was synthesized by Surmatis et al., ${ }^{16)}$ and also obtained as a hydrolysis product of (4S)-4-(hydroxymethyl)-3,5,5-trimethylcyclohex-2-enone- $\beta$-D-glucopyranoside, ${ }^{17)}$ this is the first example from the natural source.

Crocusatin-D (4a) was isolated as a colorless oil, and HRelectron impact (EI)-MS established the molecular formula as $\mathrm{C}_{10} \mathrm{H}_{16} \mathrm{O}_{3}$. The presence of an isophorone skeleton of $\mathbf{4 a}$ was indicated by a close resemblance of UV and IR spectra
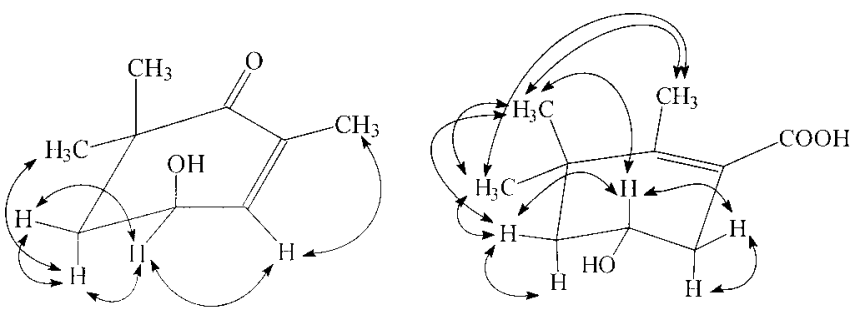

1

2a
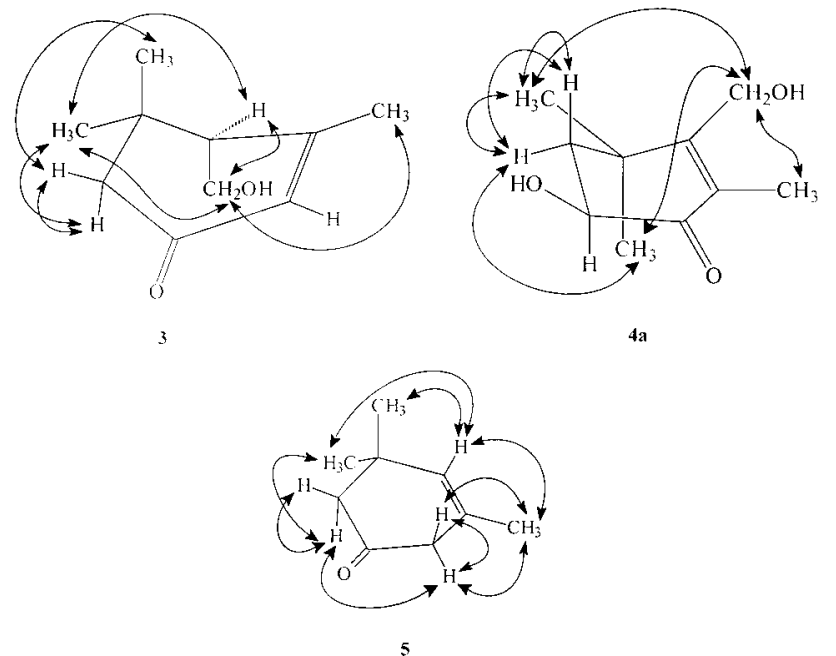

Fig. 2. The NOE Correlations of $\mathbf{1}, \mathbf{2 a}, \mathbf{3}, \mathbf{4 a}$, and $\mathbf{5}$

to that of $\mathbf{3}$. The ${ }^{1} \mathrm{H}-\mathrm{NMR}$ spectrum of $\mathbf{4 a}$ revealed signals of a gem-dimethyl group at $\delta 1.30$ and 1.24 , a vinylic methyl group at $\delta 1.94$, a hydroxymethyl group at $\delta 4.35,4.28$ (each $1 \mathrm{H}, \mathrm{d}, J=12.0 \mathrm{~Hz})$ and $\delta 3.60(1 \mathrm{H}, \mathrm{br}$ s, exchangeable with $\left.\mathrm{D}_{2} \mathrm{O}\right)$, and an ABX type protons at $\delta 2.15(1 \mathrm{H}, \mathrm{dd}, J=12.8$, $5.6 \mathrm{~Hz}), 1.78(1 \mathrm{H}, \mathrm{t}, J=12.8 \mathrm{~Hz})$ and $4.32(1 \mathrm{H}, \mathrm{dd}, J=12.8$, $5.6 \mathrm{~Hz}$ ). The downfield proton at $\delta 4.32$ was assigned to the oxygenated methine $\mathrm{H}-4$, which was supported by a carbon signal at $\delta 69.3$ in the ${ }^{13} \mathrm{C}$-NMR spectrum. The relative stereochemistry of H-4 was established as an axial orientation based on the coupling constant. In the NOESY experiment (Fig. 2), the hydroxymethyl signal appeared within NOE distance from the gem-dimethyl and vinylic methyl groups. Therefore, the hydroxymethyl group must be located at C-1. NOEs between the gem-dimethyl and H-5 were observed. On the other hand, the location of the carbonyl group at C-3 was established by the ${ }^{3} J$ correlation between the vinylic methyl proton $(\delta$ 1.94) and a carbonyl carbon $(\delta$ 201.1) in the HMBC experiment (Fig. 1). The absolute configuration at C4 was determined to be $S$ by the negative optical rotation, which was compared with $\mathbf{4 b}{ }^{18)}$ Based on the above data, structure $4 \mathbf{a}$ was assigned as crocusatin-D.

Crocusatin-E (5) was isolated as a colorless oil, and its molecular formula, $\mathrm{C}_{9} \mathrm{H}_{14} \mathrm{O}\left(\mathrm{M}^{+}\right.$at $\mathrm{m} / z$ 138.1051), indicated three degrees of unsaturation. The IR absorption band at $1710 \mathrm{~cm}^{-1}$ indicated the presence of an unconjugated carbonyl group. The ${ }^{1} \mathrm{H}-\mathrm{NMR}$ spectrum showed the presence of a gem-dimethyl group $(\delta 1.07,1.11)$, a vinylic methyl group $(\delta$ 2.04), a vinyl proton $(\delta 5.91)$ and two pairs of isolated methylene protons at $\delta 3.92,3.69$ (each $1 \mathrm{H}, \mathrm{d}, J=10.8 \mathrm{~Hz}$ ) and $\delta 2.54,2.25$ (each $1 \mathrm{H}, \mathrm{d}, J=17.6 \mathrm{~Hz}$ ). The downfield sig- 
nals at $\delta 3.92$ and 3.69 were assigned to a methylene group, which was located between the carbonyl and olefinic carbon. Based on the above data, 5 was suggested to be a $\beta, \gamma$-unsaturated ketonic structure of isophorone. ${ }^{19)}$ A NOESY experiment (Fig. 2) showed that the vinyl methyl ( $\delta$ 2.04) was within NOE distance from the vinyl proton $(\delta 5.91)$ and $\mathrm{H}-3$ $(\delta 3.69,3.92)$, and also the NOEs of vinyl proton $(\delta 5.91)$ with gem-dimethyl and vinyl methyl protons. All of the above data led to the assignment of structure 5 for crocusatin-E, which was synthesized by Kharasch et al. ${ }^{19)}$

Sodium $(2 S)$-( $O$-hydroxyphenyl)lactate $(6)$ was isolated as an optically active colorless powder. The UV absorption bands at 253, 258 and $264 \mathrm{~nm}$ were considered to be characteristic of a benzenoid. ${ }^{20)}$ The IR absorptions at 3300 and $1567 \mathrm{~cm}^{-1}$ indicated the presence of a hydroxyl group and a carbonyl group, respectively. In the ${ }^{1} \mathrm{H}-\mathrm{NMR}$ spectrum, four mutually coupled protons appearing at $\delta 7.31-7.24(3 \mathrm{H}$, $\mathrm{m})$, and $7.19(1 \mathrm{H}, \mathrm{d}, J=7.6 \mathrm{~Hz})$ were attributed to ortho-disubstituted aromatic protons. ABX pattern aliphatic protons at $\delta 3.85(1 \mathrm{H}, \mathrm{dd}, J=8.0,5.2 \mathrm{~Hz}), 3.15(1 \mathrm{H}, \mathrm{dd}, J=14.8$, $5.2 \mathrm{~Hz})$ and $2.98(1 \mathrm{H}, \mathrm{dd}, J=14.8,8.0 \mathrm{~Hz})$ were assigned to the $\alpha$ - and $\beta$-protons of an $\alpha$-hydroxy- $\beta$-arylpropanoic acid moiety. The above data for compound $\mathbf{6}$ was similar to $O$-hydroxyphenyllactic acid. However, the IR spectrum of $\mathbf{6}$ displayed carbonyl absorption at $1567 \mathrm{~cm}^{-1}$, indicating that this carbonyl should be in salt form. Acidification of 6 with $\mathrm{HCl}_{(\mathrm{aq})}$ afforded sodium chloride, which was determined with an atomic absorption spectrometer and $(S)$ - $O$-hydroxyphenyllactic acid $\left([\alpha]_{\mathrm{D}}+59^{\circ}, c=0.08, \mathrm{MeOH}\right)$. The absolute structure was determined to be $S$ by comparison with $(S)$ $(+)$-methyl 3-phenyllactate, which was synthesized in 1991 by Mash et al. and showed a positive optical rotation. ${ }^{21)}$ On the basis of the above data, structure $\mathbf{6}$ was assigned to be sodium $(2 S)$ - $(O$-hydroxyphenyl)lactate. Kenneth et al. have already synthesized $( \pm)$-sodium $O$-hydroxyphenyllactate ${ }^{22)}$; this is the first example of an optically active form from the natural source.

The 18 known compounds, 3,5,5-trimethyl-2-hydroxy-1,4cyclohexadion-2-ene (7), 2, 2,4,4-trimethyl-3-formyl-6-hydroxy-2,5-cyclohexadien-1-one (8), ${ }^{2)}$ 3,5,5-trimethyl-4-hydroxy-1-cyclohexanon-2-ene (9), ${ }^{2)}$ methylparaben $(\mathbf{1 0}),{ }^{23)}$ protocatechuic acid methyl ester (11), ${ }^{24)}$ 4-hydroxybenzoic acid (12), ${ }^{25)}$ kaempferid (13), ${ }^{26)}$ 4-hydroxyphenethyl alcohol (14), ${ }^{27)}$ benzoic acid (15), ${ }^{28)}$ pyridin-3-yl-methanol (16) ${ }^{29)}$ nicotinamide (17), ${ }^{30)}$ 1-O-(4-hydroxybenzoyl)- $\beta$-D-glucose $(\mathbf{1 8}),{ }^{31)}$ adenosine (19), ${ }^{32)}$ isorhamnetin-3,4'-diglucoside (20), ${ }^{33)}$ isorhamnetin-3-O-robinobioside $(\mathbf{2 1}),{ }^{34)}$ isorhamnetin-3- $\beta$-D-glucoside (22), ${ }^{35)}$ 5-methyluracil $(\mathbf{2 3})^{36)}$ and uracil $(\mathbf{2 4})^{37)}$ were also isolated and identified by comparison of their spectroscopic data (UV, IR and mass spectroscopy) with literature values.

Among them, compounds 2a, 6, 7, 9, 17, 19, 20, 23, 24 were subjected to evaluation of their antityrosinase activity. As a result (Table 1), isorhamnetin-3, $4^{\prime}$-diglucoside (20) inhibited tyrosinase, and its activity was stronger $\left(\mathrm{IC}_{50} \mathrm{ca}\right.$. $1.8 \mathrm{~mm}$ ) than that of arbutin $\left(\mathrm{IC}_{50} c a .24 \mathrm{~mm}\right)^{38)}$ or hydroquinone $\left(\mathrm{IC}_{50} c a .4 .5 \mathrm{~mm}\right),{ }^{39)}$ but weaker than kojic acid $\left(\mathrm{IC}_{50}\right.$ $235.2 \mu \mathrm{M}),{ }^{40)}$ which are usually present in commercial whitening cosmetics. The results suggested that the pollen of Crocus sativus could be used as an additive product in whitening cosmetics, since tyrosinase inhibitors have become
Table 1. Inhibition Effects on Tyrosinase Activity of the Constituents Isolated from the Pollen of Crocus sativus and Kojic Acid

\begin{tabular}{cccc}
\hline \hline Compound & Conc. $(\mu \mathrm{m} / \mathrm{ml})$ & Inhibition $(\%)$ & $\mathrm{IC}_{50}$ \\
\hline $\mathbf{2 a}$ & 333.3 & 11.5 & \\
& 166.7 & 5.7 & \\
$\mathbf{6}$ & 333.3 & 7.5 & \\
$\mathbf{7}$ & 333.3 & 11.3 & \\
$\mathbf{9}$ & 166.7 & 5.7 & \\
& 333.3 & 13.3 & \\
$\mathbf{1 7}$ & 166.7 & 4.6 & \\
& 333.3 & 13.5 & \\
$\mathbf{1 9}$ & 166.7 & 9.6 & \\
& 333.3 & 21.6 & \\
$\mathbf{2 0}$ & 166.7 & 5.9 & \\
& 2666.7 & 55.7 & \\
$\mathbf{2 3}$ & 1333.3 & 44.9 & \\
$\mathbf{2 4}$ & 666.7 & 34.0 & \\
Kojic acid & 333.3 & 7.8 & \\
& 333.3 & 5.3 & \\
& 333.3 & 59.8 & \\
& 166.7 & 40.2 & \\
\hline
\end{tabular}

important for cosmetic products related to hyperpigmentation.

\section{Experimental}

Melting points were measured on a Yanagimoto MP-S3 micro melting point apparatus and are uncorrected. The UV spectra were recorded on a Hitachi UV-3210 spectrophotometer in $\mathrm{MeOH}$ solution. The IR spectra were measured on a Shimadzu FTIR-8501 spectrophotometer as $\mathrm{KBr}$ disks. The ${ }^{1} \mathrm{H}-(400 \mathrm{MHz})$ and ${ }^{13} \mathrm{C}-\mathrm{NMR}(100 \mathrm{MHz})$ spectra were recorded on a Varian400 Unity Plus 400 spectrometer. Chemical shifts are shown in $\delta$ values with tetramethylsilane as an internal reference. The mass spectra were performed in the EI or FAB (matrix: glycerol) mode on a VG70-250S mass spectrometer. Optical rotations were obtained on a Jasco DIP-370 polarimeter.

Plant Material The pollen of Crocus sativus L. was bought from Shanghai and verified by Prof. C. S. Kuoh. A voucher specimen was deposited in the Herbarium of Cheng Kung University, Tainan, Taiwan.

Extraction and Separation The pollen of C. sativus L. (180 g) was extracted with $\mathrm{MeOH}(\times 5)$ at room temperature, and concentrated to give a deep brown syrup $(100 \mathrm{~g})$. The crude extract was partitioned between $\mathrm{H}_{2} \mathrm{O}$ and $\mathrm{Et}_{2} \mathrm{O}$. The $\mathrm{Et}_{2} \mathrm{O}$ layer $(40 \mathrm{~g}$ ) was directly chromatographed on a silica gel column by elution with a gradient of $n-\mathrm{C}_{6} \mathrm{H}_{14}-\mathrm{Me}_{2} \mathrm{CO}$ to afford 11 fractions. Fraction 6 underwent column chromatography over silica gel using $n$ $\mathrm{C}_{6} \mathrm{H}_{14}-$ EtOAc $(19: 1)$ as an eluent to yield $7(10 \mathrm{mg})$. Fraction 7 was also treated in a manner similar to fr. 6 to give $8(40 \mathrm{mg}), \mathbf{9}(10 \mathrm{mg})$, and $\mathbf{1}$ $(4 \mathrm{mg})$, successively. Fraction 8 was rechromatographed on a silica gel column and eluted with $\mathrm{C}_{6} \mathrm{H}_{6}-$ EtOAc $(14: 1)$ to get $\mathbf{1 0}(6 \mathrm{mg})$ and $\mathbf{2 a}(36 \mathrm{mg})$, respectively. Fraction 9 underwent column chromatography over silica gel, and was eluted with a gradient of $(i-\mathrm{Pr})_{2} \mathrm{O}-\mathrm{MeOH}$ to obtain $11(4 \mathrm{mg}), 12$ $(6 \mathrm{mg})$, and $\mathbf{1 3}(5 \mathrm{mg})$, successively. Fraction 10 was treated in a similar method as that for fr. 9 to obtain $\mathbf{1 4}(80 \mathrm{mg}), \mathbf{3}(3 \mathrm{mg}), \mathbf{4 a}(3 \mathrm{mg})$ and $\mathbf{1 5}$ $(5 \mathrm{mg})$, successively. Fraction 11 was rechromatographed on silica gel and eluted with a gradient of $\mathrm{CHCl}_{3}-\mathrm{MeOH}$ to yield $5(8 \mathrm{mg})$. The $\mathrm{H}_{2} \mathrm{O}$ soluble layer $(60 \mathrm{~g})$ was chromatographed on Diaion HP-20 and eluted with a gradient of $\mathrm{H}_{2} \mathrm{O}$ and $\mathrm{MeOH}$ to give 12 fractions. Fraction 3 was rechromatographed on silica gel using $\mathrm{CHCl}_{3}-\mathrm{MeOH}-\mathrm{H}_{2} \mathrm{O}(75: 25: 1)$ as an eluent to afford $\mathbf{6}(36 \mathrm{mg}), \mathbf{1 6}(4 \mathrm{mg})$ and $\mathbf{1 7}(12 \mathrm{mg})$, successively. Fraction 4 was column chromatographed on silica gel and eluted with $\mathrm{CHCl}_{3}-\mathrm{MeOH}-$ $\mathrm{H}_{2} \mathrm{O}(80: 20: 1)$ to give $\mathbf{1 8}(8 \mathrm{mg})$ and $\mathbf{1 9}(25 \mathrm{mg})$, respectively. Fraction 8 was treated in a similar manner to fr. 3 to afford $20(100 \mathrm{mg})$ and 21 $(280 \mathrm{mg})$, respectively. Similarly, fr. 10 underwent column chromatography over silica gel using $\mathrm{CHCl}_{3}-\mathrm{MeOH}-\mathrm{H}_{2} \mathrm{O}(75: 25: 1)$ as an eluent to yield 22 $(50 \mathrm{mg})$. Fraction 12 was rechromatographed on silica gel and eluted with $\mathrm{CHCl}_{3}$-EtOAc-MeOH-H $\mathrm{H}_{2} \mathrm{O}(60: 20: 20: 1)$ to afford $23(20 \mathrm{mg})$ and 24 $(10 \mathrm{mg})$, respectively.

Crocusatin-A (1): Colorless oil. $[\alpha]_{\mathrm{D}}-45^{\circ}(c=0.06, \mathrm{MeOH})$. HR-MS $m / z: 154.0988[\mathrm{M}]^{+}$(Calcd for $\left.\mathrm{C}_{9} \mathrm{H}_{14} \mathrm{O}_{2}: 154.0994\right)$. UV $\lambda_{\max }$ nm: 232. IR 
$v_{\max } \mathrm{cm}^{-1}: 3500,2968,2927,1672,1454,1353$. EI-MS (rel. int.) $\mathrm{m} / \mathrm{z}: 154$ $\left(\mathrm{M}^{+}, 35\right), 153$ (42), 139 (27), 123 (30), 109 (49), 91 (28), 55 (100). ${ }^{1} \mathrm{H}-\mathrm{NMR}$ $\left(\mathrm{CDCl}_{3}\right) \delta: 6.60(1 \mathrm{H}, \mathrm{d}, J=1.6 \mathrm{~Hz}, \mathrm{H}-3), 4.58(1 \mathrm{H}, \mathrm{ddd}, J=5.2,2.4,1.6 \mathrm{~Hz}$, $\mathrm{H}-4), 2.15(1 \mathrm{H}, \mathrm{dd}, J=12.8,5.2 \mathrm{~Hz}, \mathrm{H}-5), 1.83(1 \mathrm{H}, \mathrm{dd}, J=12.8,2.4 \mathrm{~Hz}, \mathrm{H}-$ 5), 1.79 (3H, s, Me-7), 1.15 (3H, s, Me-9), $1.11(3 \mathrm{H}, \mathrm{s}, \mathrm{Me}-8) .{ }^{13} \mathrm{C}-\mathrm{NMR}$ $\left(\mathrm{CDCl}_{3}\right) \delta: 203.6(\mathrm{C}-1), 145.8$ (C-3), 133.9 (C-2), 65.0 (C-4), 46.8 (C-5), 41.9 (C-6), 25.8 (C-9), 24.5 (C-8), 16.2 (C-7).

Crocusatin-B (2a): Colorless powder. $[\alpha]_{\mathrm{D}}+71^{\circ}(c=0.07, \mathrm{MeOH})$. HRMS $m / z: 184.1094[\mathrm{M}]^{+}$(Calcd for $\mathrm{C}_{10} \mathrm{H}_{16} \mathrm{O}_{3}: 184.1100$ ). UV $\lambda_{\max } \mathrm{nm}: 221$. IR $v_{\max } \mathrm{cm}^{-1}: 3365,2962,1651,1539,1434$. EI-MS (rel. int.) $\mathrm{m} / \mathrm{z}: 184\left(\mathrm{M}^{+}\right.$, 11), 169 (43), 151 (100), 121 (37), 107 (57), 95 (31). ${ }^{1} \mathrm{H}-\mathrm{NMR}\left(\mathrm{CDCl}_{3}\right) \delta$ : $3.93(1 \mathrm{H}$, dddd, $J=9.6,8.0,6.0,3.6 \mathrm{~Hz}, \mathrm{H}-4), 2.23(1 \mathrm{H}$, dd, $J=16.4,6.0 \mathrm{~Hz}$, $\left.\mathrm{H}-3_{\mathrm{eq}}\right), 1.88\left(1 \mathrm{H}, \mathrm{dd}, J=16.4,9.6 \mathrm{~Hz}, \mathrm{H}-3_{\mathrm{ax}}\right), 1.68(3 \mathrm{H}, \mathrm{Me}-7), 1.67(1 \mathrm{H}, \mathrm{dd}$, $\left.J=8.0,3.6 \mathrm{~Hz}, \mathrm{H}-5_{\mathrm{eq}}\right), 1.38\left(1 \mathrm{H}, \mathrm{t}, J=8.0 \mathrm{~Hz}, \mathrm{H}-5_{\mathrm{ax}}\right), 1.22(3 \mathrm{H}, \mathrm{s}, \mathrm{Me}-8)$, $1.12(3 \mathrm{H}, \mathrm{s}, \mathrm{Me}-9) \cdot{ }^{13} \mathrm{C}-\mathrm{NMR}\left(\mathrm{CDCl}_{3}\right) \delta: 181.6(\mathrm{C}=\mathrm{O}), 142.0(\mathrm{C}-1), 124.1$ (C-2), 65.7 (C-4), 48.8 (C-5), 41.3 (C-3), 36.4 (C-6), 30.5 (C-9), 29.6 (C-8), $21.4(\mathrm{C}-7)$.

Crocusatin-C (3): Colorless oil. $[\alpha]_{\mathrm{D}}-63^{\circ}(c=0.06, \mathrm{MeOH})$. HR-MS $m / z: 168.1156[\mathrm{M}]^{+}\left(\right.$Calcd for $\left.\mathrm{C}_{10} \mathrm{H}_{16} \mathrm{O}_{2}: 168.1151\right)$. UV $\lambda_{\max }$ nm: 239. IR $v_{\max } \mathrm{cm}^{-1}: 3350,2962,1670,1066$. EI-MS (rel. int.) $\mathrm{m} / \mathrm{z}: 168\left(\mathrm{M}^{+}, 34\right), 153$ (8), 138 (13), 123 (100), $112(40), 109$ (27). ${ }^{1} \mathrm{H}-\mathrm{NMR}\left(\mathrm{CDCl}_{3}\right) \delta: 5.98(1 \mathrm{H}$, s, H-3), $3.95(1 \mathrm{H}, \mathrm{dd}, J=11.6,3.6 \mathrm{~Hz}, \mathrm{H}-7 \mathrm{a}), 3.88(1 \mathrm{H}, \mathrm{dd}, J=11.6,3.6 \mathrm{~Hz}$, H-7b), $2.63\left(1 \mathrm{H}, \mathrm{d}, J=17.2 \mathrm{~Hz}, \mathrm{H}-5_{\mathrm{eq}}\right), 2.05\left(1 \mathrm{H}, \mathrm{d}, J=17.2 \mathrm{~Hz}, \mathrm{H}-5_{\mathrm{ax}}\right), 2.03$ $(3 \mathrm{H}, \mathrm{s}, \mathrm{Me}-8), 1.99(1 \mathrm{H}, \mathrm{t}, J=3.6 \mathrm{~Hz}, \mathrm{H}-1), 1.15(3 \mathrm{H}, \mathrm{s}, \mathrm{Me}-9), 1.03(3 \mathrm{H}, \mathrm{s}$, Me-10). ${ }^{13} \mathrm{C}-\mathrm{NMR}\left(\mathrm{CDCl}_{3}\right) \delta: 199.7(\mathrm{C}-4), 160.8(\mathrm{C}-2), 127.6(\mathrm{C}-3), 61.5$ (C-7), 53.6 (C-1), 48.5 (C-5), 35.4 (C-6), 29.4 (C-10), 27.1 (C-9), 23.9 (C$8)$.

Crocusatin-D (4a): Colorless oil. $[\alpha]_{\mathrm{D}}-42^{\circ}(c=0.07, \mathrm{MeOH})$. HR-MS $m / z: 184.1108[\mathrm{M}]^{+}$(Calcd for $\mathrm{C}_{10} \mathrm{H}_{16} \mathrm{O}_{3}: 184.1100$ ). UV $\lambda_{\max } \mathrm{nm}: 247$. IR $v_{\max } \mathrm{cm}^{-1}: 3561,2963,1677,1673$, 1083. EI-MS (rel. int.) $\mathrm{m} / \mathrm{z}: 184\left(\mathrm{M}^{+}\right.$ 3), 166 (56), 140 (57), 135 (10), 125 (100), 95 (40). ${ }^{1} \mathrm{H}-\mathrm{NMR}\left(\mathrm{CDCl}_{3}\right) \delta$ : $4.35(1 \mathrm{H}, \mathrm{d}, J=12.0 \mathrm{~Hz}, \mathrm{H}-10 \mathrm{a}), 4.32(1 \mathrm{H}, \mathrm{dd}, J=12.8,5.6 \mathrm{~Hz}, \mathrm{H}-4), 4.28$ $(1 \mathrm{H}, \mathrm{d}, J=12.0 \mathrm{~Hz}, \mathrm{H}-10 \mathrm{~b}), 3.60(1 \mathrm{H}, \mathrm{br},-\mathrm{OH}), 2.15(1 \mathrm{H}, \mathrm{dd}, J=12.8$, $\left.5.6 \mathrm{~Hz}, \mathrm{H}-5_{\mathrm{eq}}\right), 1.94(3 \mathrm{H}, \mathrm{s}, \mathrm{Me}-7), 1.78\left(1 \mathrm{H}, \mathrm{t}, J=12.8 \mathrm{~Hz}, \mathrm{H}-5_{\mathrm{ax}}\right), 1.30(3 \mathrm{H}$, $\mathrm{s}, \mathrm{Me}-8), 1.24(3 \mathrm{H}, \mathrm{s}, \mathrm{Me}-9) .{ }^{13} \mathrm{C}-\mathrm{NMR}\left(\mathrm{CDCl}_{3}\right) \delta: 201.1(\mathrm{C}-3), 161.0(\mathrm{C}-$ 1), 130.7 (C-2), 69.3 (C-4), 59.2 (C-10), 45.3 (C-5), 36.5 (C-6), 29.1 (C-9), $25.2(\mathrm{C}-8), 11.4(\mathrm{C}-7)$

Crocusatin-E (5): Colorless oil. HR-MS m/z: $138.1051[\mathrm{M}]^{+}$(Calcd for $\left.\mathrm{C}_{9} \mathrm{H}_{14} \mathrm{O}: 138.1045\right)$. IR $v_{\max } \mathrm{cm}^{-1}: 2963,2927,1710,1489,1375,1281$. EIMS (rel. int.) $m / z$ : $138\left(\mathrm{M}^{+}, 13\right), 123(24), 107(57), 83(59), 57(100) .{ }^{1} \mathrm{H}-$ NMR $\left(\mathrm{CDCl}_{3}\right) \delta: 5.91(1 \mathrm{H}, \mathrm{s}, \mathrm{H}-1), 3.92\left(1 \mathrm{H}, \mathrm{d}, J=10.8 \mathrm{~Hz}, \mathrm{H}-3_{\mathrm{ax}}\right), 3.69$ $\left(1 \mathrm{H}, \mathrm{d}, J=10.8 \mathrm{~Hz}, \mathrm{H}-3_{\mathrm{eq}}\right), 2.54\left(1 \mathrm{H}, \mathrm{d}, J=17.6 \mathrm{~Hz}, \mathrm{H}-5_{\mathrm{ax}}\right), 2.25(1 \mathrm{H}, \mathrm{d}$, $\left.J=17.6 \mathrm{~Hz}, \mathrm{H}-5_{\mathrm{eq}}\right), 2.04(3 \mathrm{H}, \mathrm{s}, \mathrm{Me}-7), 1.11(3 \mathrm{H}, \mathrm{s}, \mathrm{Me}-9), 1.07$ (3H, s, Me8). ${ }^{13} \mathrm{C}-\mathrm{NMR}\left(\mathrm{CDCl}_{3}\right) \delta: 197.7(\mathrm{C}-4), 127.9(\mathrm{C}-1), 126.6(\mathrm{C}-2), 65.2(\mathrm{C}-3)$, 49.7 (C-5), 40.8 (C-6), 29.9 (C-9), 23.9 (C-8), 20.3 (C-7).

Sodium $(2 S)-\left(O\right.$-hydroxyphenyl) lactate $(6)$ : Colorless powder. $[\alpha]_{\mathrm{D}}+77^{\circ}$ $(c=0.07, \mathrm{MeOH})$. UV $\lambda_{\max } \mathrm{nm}: 253,258,264$. IR $v_{\max } \mathrm{cm}^{-1}: 3300,2963$, $1567,1495,1307 .{ }^{1} \mathrm{H}-\mathrm{NMR}\left(\mathrm{D}_{2} \mathrm{O}\right) \delta: 7.31-7.24\left(3 \mathrm{H}, \mathrm{m}, \mathrm{H}-4^{\prime}, \mathrm{H}-6^{\prime}, \mathrm{H}-5^{\prime}\right)$, $7.19\left(1 \mathrm{H}, \mathrm{d}, J=7.6 \mathrm{~Hz}, \mathrm{H}-3^{\prime}\right), 3.85(1 \mathrm{H}, \mathrm{dd}, J=8.0,5.2 \mathrm{~Hz}, \mathrm{H}-2), 3.15(1 \mathrm{H}$, dd, $J=14.8,5.2 \mathrm{~Hz}, \mathrm{H}-3), 2.98(1 \mathrm{H}$, dd, $J=14.8,8.0 \mathrm{~Hz}, \mathrm{H}-3) .{ }^{13} \mathrm{C}-\mathrm{NMR}$ $\left(\mathrm{D}_{2} \mathrm{O}+\mathrm{DMSO}-d_{6}\right) \delta$ : $175.8(\mathrm{C}-1), 137.0\left(\mathrm{C}-2^{\prime}\right), 131.2-131.0\left(\mathrm{C}-4^{\prime}, \mathrm{C}-6^{\prime}\right.$, C-5', C-1'), $129.6\left(\mathrm{C}-3^{\prime}\right), 57.8(\mathrm{C}-2), 38.2(\mathrm{C}-3)$.

Acidification of 6: $6(2 \mathrm{mg})$ was dissolved in $1 \mathrm{ml} 5 \% \mathrm{HCl}_{(\mathrm{aq})}$. The solution was eluted on a Sephadex LH-20 column with $\mathrm{H}_{2} \mathrm{O}$ to afford $\mathrm{NaCl}$ $(0.5 \mathrm{mg})$, which was determined with an atomic absorption spectrometer. It was then eluted with $\mathrm{MeOH}$ to give $(2 S)$-( $O$-hydroxyphenyl) lactic acid $(1.4 \mathrm{mg})\left([\alpha]_{\mathrm{D}}+59^{\circ}, c=0.08, \mathrm{MeOH}\right)$.

Tyrosinase Inhibitory Activity The mushroom tyrosinase and L-dopa used for the bioassay were purchased from Sigma Chemical Co. Antityrosinase activity was measured by spectrophotometry according to the method of Mason and Peterson, ${ }^{41)}$ with minor modifications. The test substance was dissolved in $0.1 \mathrm{ml}$ DMSO- $\mathrm{H}_{2} \mathrm{O}(10 \%$ DMSO solution) and incubated with $0.1 \mathrm{ml}$ mushroom tyrosinase $(135 \mathrm{U} / \mathrm{ml}$, PBS $\mathrm{pH} 6.8)$ at $25^{\circ} \mathrm{C}$ for $10 \mathrm{~min}$, then $0.1 \mathrm{ml} 0.5 \mathrm{~mm}$ L-dopa phosphate buffer solution (PBS, pH 6.8) was added. The reaction mixture was incubated for $5 \mathrm{~min}$. The amount of dopachrome in the mixture was determined by the optical density (OD) at $475 \mathrm{~nm}$ using a $\mu$ Quant universal microplate spectrophotometer. Kojic acid (Sigma Chemical Co.) was used as a standard agent. The inhibitory percentage of tyrosinase was calculated as follows:

$\%$ inhibition $=\{[(A-B)-(C-D)] /(A-B)\} \times 100$

$A$ : $\quad$ OD at $475 \mathrm{~nm}$ without test substance

$B$ : OD at $475 \mathrm{~nm}$ without test substance and tyrosinase

$C$ : $\quad$ OD at $475 \mathrm{~nm}$ with test substance

\section{$D: \quad$ OD at $475 \mathrm{~nm}$ with test substance, but without tyrosinase}

Acknowledgements We thank the National Science Council, Republic of China, for financial support of this research (NSC-89-2113-M-006-032). We also thank Professor C. S. Kuoh (Department of Biology, National Cheng Kung University, Tainan, Taiwan) and Professor H. M. Wu (Institute of Shanghai Organic Chemistry, Academia Sinica) for the plant identification and collection, respectively.

\section{References}

1) Jiangsu New Medical College, "Encyclopedia of Chinese Materia Medica," Vol. 2, Shanghai Science and Technology Press, Shanghai, 1977, pp. 2671-2672.

2) Zarghami N. S., Heinz D. E., Phytochemistry, 10, 2755-2761 (1971).

3) Dhingra V. K., Seshadri T. R., Mukerjee S. K., Indian J. Chem., 13, 339-341 (1975).

4) Pfander H., Rychener M., J. Chromatogr., 234, $443-447$ (1982).

5) Ghosal S., Singh S. K., Battacharrya S. K., J. Chem. Res. (S), 1989, 70-71 (1989).

6) Castellar M. R., Montijano H., Manjon A., Iborra J. L., J. Chromatogr., 648, 187-190 (1993).

7) Tarantilis P. A., Tsoupras G., Polissiou M., J. Chromatogr. A, 699, 107-118 (1995).

8) Rios J. L., Recio M. C., Giner R. M., Manez S., Phytother. Res., 10, 189-193 (1996).

9) Nair S. C., Pannikar B., Panikkar K. R., Cancer Lett., 57, 109-114 (1991).

10) Salomi M. J., Nair S. C., Panikkar K. R., Nutr. Cancer, 16, 67-72 (1991).

11) Abdullaev F. I., Toxic. Lett., 70, 243-251 (1994).

12) Song C. Q., Zhongcaoyao, 21, 439-441 (1990).

13) Song C. Q., Xu R. S., Acta Chim. Sin., 49, 917-920 (1991).

14) Widmer E., Zell R., Lukac T., Casadei M., Schoenholzer P., Broger E. A., Helv. Chim. Acta, 64, 2405-2418 (1981).

15) Takesa Y., Nishimura H., Kadota O., Chem. Pharm. Bull., 24, 2644 2646 (1976).

16) Surmatis J. D., Walser A., Gibas J., Thommen R., J. Org. Chem., 35, 1053-1056 (1970).

17) Straubinger M., Jezussek M., Waibel R., Winthrhalter P., J. Agric. Food Chem., 45, 1678-1681 (1997).

18) Yamana Y., Sato Y., Watanabe Y., Koshi N., Wataru M., Masayoshi I., J. Chem. Soc., Perkin Trans. 1, 2001, 1862-1869 (2001).

19) Kharasch M. S., Tawney P. O., J. Am. Chem. Soc., 63, 2308-2313 (1941).

20) Wu T. S., Leu Y. L., Chan Y. Y., Chem. Pharm. Bull., 46, 1624-1626 (1998).

21) Mash E. A., Arterburn J. B., Fryling J. A., Mitchell S. H., J. Org. Chem., 56, 1088-1093 (1991).

22) Kenneth N. F. S., Armand M., Marvin D. A., J. Org. Chem., 21, 601604 (1956).

23) Carter M. J., Fleming I., Percival A., J. Chem. Soc., Perkin Trans. 1, 1981, 2415-2434 (1981).

24) Ikeya Y., Taguchi H., Yoshioka I., Chem. Pharm. Bull., 29, 28932898 (1981).

25) Honma K., Kuroiwa Y., Hamada A., Chem. Pharm. Bull., 23, 17451751 (1975)

26) Quijano L., Trejo R. I., Collera O., Rios T., Phytochemistry, 36, 1443-1448 (1994).

27) Giuseppe P. F., Servi S., J. Chem. Soc., Perkin Trans. 1, 1992, 10291034 (1992).

28) Fernandez I., Garcia B., Grancha F. J., Pedro J. R., Phytochemistry, 28, 2405-2408 (1989).

29) Ito A., Kasai R., Yamasaki K., Sugimoto H., Phytochemistry, 33, 1133-1137 (1993).

30) Reifield A. G., Waslder S., J. Am. Chem. Soc., 101, 6151-6162 (1979).

31) Klick S., Herrmann K., Phytochemistry, 27, 2177-2180 (1988).

32) Karlik S. J., Elgavish G. A., Eichhorn G. L., J. Am. Chem. Soc., 105, 602-609 (1983).

33) Oldriska C., Derok S. E., Phytochemistry, 23, 1822-1823 (1984).

34) Adell J., Barbera O., Marco J. A., Phytochemistry, 27, 2967-2970 (1988).

35) Strack D., Heilemann J., Wray V., Dirks H., Phytochemistry, 28, 2071-2078 (1989) 
36) Claydon N., Grove J. F., Pople M., Phytochemistry, 24, 937—943 (1985).

37) Schneider H. J., Blatter T., Palm B., Pfingstag U., Ruediger V., Theis I., J. Am. Chem. Soc., 114, 7704-7708 (1992).

38) Kubo I., Kinst-Hori I., Planta Med., 65, 19-22 (1999).
39) Maeda K., Fukuda M., J. Soc. Cosmet. Chem., 42, 361-368 (1991).

40) Ryuju H., Senji T., Kunikatsu H., Tadasu M., Akira N., Biosci. Biotechnol. Biochem., 58, 1725-1726 (1994).

41) Mason H. S., Peterson E. W., Biochem. Biophys. Acta, 111, 134-139 (1965). 